\title{
Kandungan Bilangan Peroksida Minyak Goreng Pedagang di Jalan Perintis Kemerdekaan Kota Padang
}

\author{
Intan Permata Sari Syafrudin ${ }^{1}$, Asterina $^{2}$, Russilawati ${ }^{3}$ \\ ${ }^{1}$ Profesi Dokter Fakultas Kedokteran Universitas Andalas Padang \\ ${ }^{2}$ Bagian Kimia Fakultas Kedokteran Universitas Andalas Padang \\ ${ }^{3}$ Bagian Paru dan Kedokteran Respirasi FK UNAND/RSUP Dr. M. Djamil Padang
}

A B S T R A C T

\begin{abstract}
Latar Belakang. Masyarakat Indonesia sering menggunakan minyak goreng secara berulang dalam proses penggorengan seperti dijumpai pada pedagang kuliner di tepi jalan. Mengonsumsi minyak tersebut dapat menyebabkan gangguan pada hati, pembuluh darah, jantung dan keganasan.

Objektif. Tujuan dari penelitian ini adalah untuk mendeskripsikan dan menganalisis jumlah bilangan peroksida pada minyak goreng yang digunakan oleh pedagang di Jalan Perintis Kemerdekaan Kota Padang.

Metode. Penelitian ini adalah penelitian deksriptif. Sampel penelitian diperoleh menggunakan metode purposive sampling dan didapatkan 23 sampel minyak goreng yang digunakan oleh pedagang pecel lele dan ayam serta pedagang gorengan. Penelitian dilakukan di UPTD Balai Laboratorium Kesehatan Sumatera Barat dari bulan Oktober 2019 sampai Mei 2020.

Hasil. Penelitian menunjukkan bahwa 14 dari 23 minyak goreng yang digunakan pedagang memiliki bilangan peroksida diatas ketetapan Standar Nasioanl Indonesia (SNI) 01-37412013. Rerata bilangan peroksida pada pedangan gorengan yaitu $15,10 \mathrm{mEq} \mathrm{O}_{2} / \mathrm{kg}$ sedangkan pada pedagang pecel lele dan ayam yaitu $10,29 \mathrm{mEq} \mathrm{O}_{2} / \mathrm{kg}$. Jenis minyak goreng yang digunakan memiliki rerata bilangan peroksida yaitu curah $10,81 \mathrm{mEq} \mathrm{O} \mathrm{O}_{2} / \mathrm{kg}$, bermerek $14,64 \mathrm{mEq} \mathrm{O}_{2} / \mathrm{kg}$ dan campuran $16,28 \mathrm{mEq} \mathrm{O}_{2} / \mathrm{kg}$.

Kesimpulan. Lebih dari setengah sampel yang diuji memiliki nilai bilangan peroksida melebihi nilai maksimum ( $>10 \mathrm{mEq}$ $\mathrm{O}_{2} / \mathrm{kg}$ ) dan rerata bilangan peroksida tertinggi terdapat pada pedagang gorengan dan jenis minyak goreng yang digunakan secara campuran.
\end{abstract}

Kata kunci: bilangan peroksida, minyak goreng, pedagang

Background. Indonesian usually using repeatedly cooking oil for deep frying process. The repeated use of cooking oil can be found among street vendors. Consumption of repeatedly cooking oil could lead to hepatic disorder, cardiovasular disorder and even cancer.

objective. The research aims to describe and analyze peroxide value in cooking oil used by street vendors in Perintis Kemerdekaan street in Padang City.

Methods. This is a descriptive research. The reseacrh objects were taken by purposive sample method and 23 samples cooking oil used by traders. This research was conducted at
Clinical Laboratory of West Sumatera from October 2019 to May 2020.

Results. This research found out 14 from 23 of cooking oil used by street vendors have peroxide value above the Indonesian National Standard (abbreviated SNI) 01-3741-2013. Cooking oil used by fritter street vendors have average peroxide value is $15.10 \mathrm{mEq} \mathrm{O2} / \mathrm{kg}$ while pecel catfish and chicken street vendors is $10.29 \mathrm{mEq} \mathrm{O2} / \mathrm{kg}$. The avarage peroxide value in each type of cooking oil are bulk $10,81 \mathrm{mEq} \mathrm{O}_{2} / \mathrm{kg}$, branded $14,64 \mathrm{mEq} \mathrm{O}_{2} / \mathrm{kg}$ and mixture $16,28 \mathrm{mEq} \mathrm{O}_{2} / \mathrm{kg}$.

Conclusion. More than half of the samples tested had exceed the maximum peroxide values (> $10 \mathrm{mEq} \mathrm{O}_{2} / \mathrm{kg}$ ) and the highest average are found in fritter street vendor and mixture of bulk and branded cooking oil.

Keywords: cooking oil, peroxide value, traders

Apa yang sudah diketahui tentang topik ini? Suhu yang tinggi saat penggorengan, adanya kontak minyak dengan oksigen, pemanasan berulang dan tingginya kandungan asam lemak akan mempercepat proses pembentukan peroksida pada proses oksidasi minyak goreng.

\section{Apa yang ditambahkan pada studi ini?}

Lebih dari setengah sampel minyak goreng yang digunakan oleh pedagang memiliki bilangan peroksida melebihi nilai standar mutu SNI ( $>10 \mathrm{mEq} \mathrm{O}_{2} / \mathrm{kg}$ ). Rerata bilangan peroksida tertinggi terdapat pada pedagang gorengan dan jenis minyak goreng yang digunakan secara campuran.

\section{CORRESPONDING AUTHOR}

Phone: +6281363064764

E-mail: asterinadewanti@gmail.com

\section{ARTICLE INFORMATION}

Received: August $2^{\text {nd }}$, 2020

Revised: April $9^{\text {th }}, 2021$

Available online: May $27^{\text {th }}, 2021$ 


\section{Pendahuluan}

Minyak Goreng merupakan kebutuhan pokok manusia yang sangat penting dalam pengolahan makanan dan sebagai sumber energi yang efektif jika dibandingankan dengan makronutrien lainnya seperti karbohidrat dan protein. Minyak dapat menghasilkan 9 kkal per 1 gram sedangkan karbohidrat dan protein masingmasing menghasilkan 4 kkal per 1 gram. Minyak mengandung vitamin A, D, E, K dan asam lemak esensial. ${ }^{1}$ Kebutuhan akan minyak goreng terus meningkat setiap tahunnya. Pada tahun 2018, rata-rata konsumsi minyak goreng per kapita seminggu penduduk Indonesia sebesar 0,227 liter. ${ }^{2}$ Minyak goreng banyak digunakan karena merupakan penghantar panas yang baik dan mampu memberikan kesan rasa gurih dan renyah pada makanan. Selama proses penggorengan terjadi reaksi kimia yang kompleks seperti oksidasi, hidrolisis, polimerisasi dan dekomposisi minyak yang dapat dipengaruhi oleh beberapa faktor seperti udara, suhu, lama pemanasan, kejenuhan minyak dan bahan pangan. Bahan pangan yang digoreng akan menyerap minyak goreng sehingga dapat menyebabkan perubahan pada cita rasa makanan.3,4

Proses oksidasi yang terjadi pada proses penggorengan menyebabkan perubahan pada ikatan rangkap lemak tidak jenuh yang terkandung dalam minyak goreng dikarenakan minyak berkontak dengan udara dan akan membentuk lipid peroksida. ${ }^{1}$ Suhu yang tinggi, paparan cahaya dan dipanaskan secara terus menerus juga dapat mempercepat proses oksidasi. 5,6 Senyawa aldehid, keton, dan senyawa aromatis yang dihasilkan dari proses oksidasi dapat menyebabkan ketengikan pada minyak goreng. ${ }^{6}$ Faktor lain yang dapat mempercepat proses oksidasi adalah proses penggorengan yang dilakukan secara berulang-ulang sehingga mengakibatkan terjadinya reaksi oksidasi yang lebih tinggi serta terjadi peningkatan bilangan peroksida. $^{7}$

Senyawa peroksida yang terbentuk dari proses oksidasi merupakan senyawa radikal bebas yang dapat menjadi parameter untuk mengukur mutu dan tingkat kerusakan pada minyak goreng. ${ }^{1}$ Minyak yang sudah mengalami kerusakan akan terjadi perubahan warna yang terlihat berwarna coklat tua sampai kehitaman yang disebut sebagai minyak bekas atau minyak jelantah. ${ }^{8}$ Perubahan warna menjadi warna gelap disebabkan oleh tokoferol yang terkandung di dalam minyak mengalami proses oksidasi, serta perubahan menjadi warna coklat juga disebebkan oleh reaksi molekul karbohidrat dengan aldehid dan protein. ${ }^{1}$ Syarat mutu bilangan peroksida minyak goreng menurut Standar Nasional Indonesia (SNI) 01-3741-2013 yaitu maksimal 10 meq/1kg. ${ }^{9}$ Apabila minyak goreng memiliki bilangan peroksida diatas ketetapan SNI tersebut maka minyak tidak layak untuk dikonsumsi. Masyarakat pada umumnya menggunakan minyak goreng secara berulang atau lebih dari 1 kali dengan menggunakan suhu yang tinggi. ${ }^{10} \mathrm{Hal}$ ini dapat menyebabkan kerusakan pada minyak goreng serta dapat mempengaruhi kualitas dan nilai gizi dari bahan pangan yang digoreng tersebut. ${ }^{1}$

Mengonsumsi minyak jelantah atau bekas ini dapat berdampak pada kesehatan. Beberapa penelitian yang dilakukan menujukkan peningkatan risiko terhadap beberapa penyakit, diantaranya penurunan daya cerna lemak, iritasi saluran pencernaan serta gangguan endotel berupa terbentuknya plak aterosklerotik yang dapat menyumbat pembuluh darah. ${ }^{11}$ Radikal bebas tersebut juga dapat menyebabkan iskemik miokardium dikarenakan aliran darah yang menurun menuju jantung. Hal ini dapat menyebabkan terjadinya nekrosis pada sel otot jantung. ${ }^{12}$ Radikal bebas yang terdapat dalam minyak jelantah juga dapat menyebabkan kematian sel dikarenakan terganggunya permeabilitas membran, homeostasis osmotik, dan integritas dari beberapa enzim serta konsumsi dalam jangka panjang dapat menyebabkan kanker.11,12 Dampak lainnya terhadap kesehatan dan organ tubuh terlihat dari hasil penelitian yang dilakukan oleh Ika Dkk terhadap mencit yang diinduksi dengan minyak goreng bekas atau jelantah menunjukan kerusakan pada sel hati mencit dan juga terjadi peningkatan kadar kolesterol pada mencit tersebut. 13

Penggunakan minyak goreng berulang pada masyarakat dapat dijumpai salah satunya pada pedagang makanan. Penelitian di Bogor menggunakan sampel minyak goreng jelantah yang diperoleh dari pedagang pecel lele yang berwarna hitam dan minyak goreng yang diperoleh dari pedagang gorengan yang berwarna

Intan Permata Sari Syafrudin 
coklat menunjukan kandungan bilangan peroksida dari kedua sampel tersebut melebihi nilai SNI yaitu 10 meq $/ 1 \mathrm{~kg} .{ }^{14}$ Pada tahun 2018, penelitian di Kota Semarang juga menunjukan minyak yang digunakan berulang kali memiliki bilangan peroksida yang melebihi nilai SNI dengan keseluruhan sampel berjumlah dua puluh lima yang berasal dari pedagang gorengan di Kecamatan Tembalang. ${ }^{15}$ Di Kota Padang, penggunaan minyak goreng berulang ini dapat dijumpai salah satunya di wilayah Kota Padang yaitu Jalan Perintis Kemerdekaan pada pedagang gorengan dan berbagai macam kuliner lainnya. Jalan Perintis Kemerdekaan merupakan daerah yang telah disurvei banyak ditemui penjual gorengan dibandingkan daerah lainnya di Kota Padang. ${ }^{16}$ Survei secara langsung yang dilakukan di wilayah tersebut, terdapat banyak pedagang yang menggunakan minyak goreng kelapa sawit secara berulang-ulang hingga terjadi perubahan warna pada minyak yang digunakan seperti ditemui pada pedagang pecel lele dan ayam serta gorengan yang sangat diminati di wilayah tersebut. Oleh sebab itu, perlu pengawasan ketat oleh Badan Pengawasan Obat dan Makanan (BPOM) dalam penggunaan minyak goreng oleh pedagang tersebut.

Penelitian ini bertujuan untuk mendekripsikan dan menganalisis jumlah bilangan peroksida pada minyak goreng yang digunakan oleh pedagang di Jalan Peritis Kemerdekaan Kota Padang. Hasil pengujian bilangan peroksida minyak goreng akan dibandingkan dengan Standar Mutu Minyak Goreng menurut SNI 01-3741-2013.

\section{Metode}

Jenis penelitian ini adalah deskriptif yaitu untuk mengetahui kandungan bilangan peroksida pada minyak goreng yang digunakan oleh pedagang di Jalan Peritis Kemerdekaan Kota Padang. Penelitian dilakukan dari bulan Oktober 2019 sampai Mei 2020 di UPTD Balai Laboratorium Kesehatan Sumatera Barat.

Populasi pada penelitian ini adalah minyak goreng kelapa sawit yang diperoleh dari pedagang kaki lima dan restoran kecil yang berjualan di malam di Jalan Perintis Kemerdekaan Kota Padang yang berjumlah 23 yang terdiri dari pedagang pecel lele, pecel ayam dan gorengan selama tanggal 23 februari sampai 5 maret 2020 .
Untuk menentukan jumlah sampel dapat digunakan rumus Slovin. Didapatkan besar sampel minimal yang harus diteliti adalah sejumlah 23 minyak goreng kelapa sawit. Sampel penelitian dipilih secara purposive sampling dengan kriteria inklusi yaitu minyak goreng kelapa sawit yang digunakan pedagang pecel lele dan ayam, serta pedagang gorengan di Jalan Perintis Kemerdekaan Kota Padang, sudah dilakukan lebih dari 3 kali penggorengan dan pedagang bersedia untuk dijadikan sampel. Sampel tumpah dan tercampur dengan air pada saat pengambilan harus dieklusikan.

Data diperoleh dari hasil titrasi menggunakan natrium tiosulfat $0,1 \mathrm{~N}$ yang telah distandarisasi dengan kalium iodida 0,1N. Prinsip penentuan peroksida yaitu dengan melihat hasil akhir titrasi ditandai dengan perubahan warna saat ditambah indikator berubah menjadi bening. Data dianalisis secara univariat yang menghasilkan distribusi frekuensi dan persentase dari variabel.

Hasil

Sebanyak 23 sampel minyak goreng kelapa sawit yang digunakan oleh pedagang di Jalan Perintis Kemerdekaan dilakukan pemberian label pada semua sampel minyak goreng, dilakukan standarisasi larutan $\mathrm{Na}_{2} \mathrm{~S}_{2} \mathrm{O}_{3}$ dan kemudian dilakukan pengujian bilangan peroksida sesuai prosedur. Minyak goreng kelapa sawit diambil dari pecel lele, pecel ayam dan gorengan. Hasil penelitian yang telah dilakukan sebagai berikut:

Tabel 1 Karakterisitik Pedagang dan Minyak Goreng yang Digunakan Pedagang Di Jalan Perintis Kemerdekaan Kota Padang

\begin{tabular}{lll}
\hline Karakteristik & F & \% \\
\hline Jenis Dagangan & 12 & 52 \\
Pecel Lele dan Ayam & 11 & 48 \\
Gorengan & & \\
Jenis Minyak & 13 & 56 \\
$\quad$ Curah & 8 & 35 \\
Bermerek & 2 & 9 \\
Campuran & & \\
\hline
\end{tabular}

Hasil penelitian menunjukkan bawah dari 23 sampel minyak goreng kelapa sawit terdiri dari $52 \%$ pedagang pecel lele dan ayam serta $48 \%$ pedagang gorengan. Jenis minyak yang paling 
banyak digunakan oleh pedagang adalah minyak goreng curah (56\%).

Tabel 2 Kadar Bilangan Peroksida Minyak Goreng yang Digunakan Oleh Pedagang Di Jalan Perintis Kemerdekaan Kota Padang

\begin{tabular}{|c|c|c|}
\hline Sampel & $\begin{array}{l}\text { Rerata } \\
\text { (mEq } \\
\mathrm{O}_{2} / \mathrm{Kg} \text { ) }\end{array}$ & $\begin{array}{l}\text { Minimum- } \\
\text { Maximum } \\
\left(\mathrm{mEq} \mathrm{O}_{2} / \mathrm{Kg}\right)\end{array}$ \\
\hline $\begin{array}{l}\text { Jenis Dagangan } \\
\text { Pecel Lele dan Ayam } \\
\text { Gorengan }\end{array}$ & $\begin{array}{l}10,29 \\
15,10\end{array}$ & $\begin{array}{l}6,39-19,17 \\
8,52-23,43\end{array}$ \\
\hline $\begin{array}{l}\text { Jenis Minyak } \\
\text { Curah } \\
\text { Bermerek } \\
\text { Campuran }\end{array}$ & $\begin{array}{l}10,8 \\
14,64 \\
16,28\end{array}$ & $\begin{array}{l}6,39-17,04 \\
6,39-23,43 \\
12,78-19,17\end{array}$ \\
\hline
\end{tabular}

Hasil penelitian secara kuantitatif menunjukan bahwa rerata bilangan peroksida tertinggi adalah pada pedagang gorengan yaitu $15,10 \mathrm{mEq} \mathrm{O}_{2} / \mathrm{kg}$ dengan bilangan peroksida tertinggi yaitu $23,43 \mathrm{mEq} \mathrm{O}_{2} / \mathrm{kg}$ sedangkan rerata bilangan peroksida pada pedagang pecel lele dan ayam yaitu $10,29 \mathrm{mEq} \mathrm{O}_{2} / \mathrm{kg}$ dengan bilangan peroksida tertinggi sebesar $19,17 \mathrm{mEq} \mathrm{O}_{2} / \mathrm{kg}$. Bilangan peroksida dari jenis minyak goreng yang digunakan oleh Pedagang di Jalan Perintis Kemerdekaan Kota Padang menunjukan rerata tertinggi pada minyak goreng kelapa sawit campuran yaitu $16,28 \mathrm{mEq} \mathrm{O}_{2} / \mathrm{kg}$.

Tabel 3 Distribusi Frekuensi Bilangan Peroksida pada Minyak Goreng yang Digunakan oleh Pedagang Pecel Lele, Pecel Ayam dan Gorengan Sesuai Standar Mutu Minyak Goreng yang Ditetapkan SNI

\begin{tabular}{llll}
\hline No & Sampel & F & \% \\
\hline \multirow{2}{*}{1} & Minyak Goreng Curah & & \\
& Sesuai standar Mutu SNI & 7 & 53,84 \\
& Tidak sesuai standar Mutu SNI & 6 & 46,16 \\
\hline \multirow{2}{*}{2} & Minyak Goreng Merek & & \\
$\quad$ Sesuai standar Mutu SNI & 2 & 25 \\
& Tidak sesuai standar Mutu SNI & 6 & 75 \\
\hline \multirow{2}{*}{3} & Minyak Goreng Campuran & & \\
& Sesuai standar Mutu SNI & 0 & 0 \\
& Tidak sesuai standar Mutu SNI & 2 & 100 \\
\hline
\end{tabular}

Hasil penelitian menunjukkan bahwa bilangan peroksida pada minyak goreng yang digunakan oleh pedagang pecel lele, pecel ayam dan gorengan di Jalan Perintis Kemerdekaan Kota Padang sebanyak 46,16\% minyak goreng jenis curah, $75 \%$ minyak goreng jenis merek dan $100 \%$ minyak goreng campurang yang tidak sesuai dengan standar mutu yang ditetapkan SNI yaitu maksimal $10 \mathrm{mEq} \mathrm{O}_{2} / \mathrm{kg}$.

\section{Pembahasan}

Berdasarkan hasil penelitian yang dilakukan di UPTD Balai Laboratorium Kesehatan Sumatera Barat terhadap 23 sampel minyak goreng yang digunakan pedagang di Jalan Perintis Kemerdekaan Kota Padang menunjukan pedagang menggunakan minyak goreng jenis curah, merek, dan campuran. Sebanyak 56\% pedagang menggunakan minyak goreng jenis curah, 35\% menggunakan minyak goreng bermerek atau kemasan dan $9 \%$ pedagang yang mencampurkan kedua jenis minyak goreng dalam proses penggorengan bahan makanan yang akan dijual. Terlihat dari persentase diatas bahwa jenis minyak curah banyak digunakan oleh pedagang.

Perbedaan dari jenis minyak goreng curah atau tanpa kemasan dan bermerek terletak pada proses penyaringannya dan tambahan antioksidan dimana minyak goreng kelapa sawit curah hanya dilakukan satu kali penyaringan dan tidak ditambah zat antioksidan sedangkan minyak goreng kelapa sawit kemasan bermerek mengalami dua kali penyaringan dan ditambahkan zat antioksidan yang dapat menghambat pembentukan peroksida. ${ }^{17,18}$

Nilai rerata bilangan peroksida dari 3 jenis minyak yang paling tinggi adalah minyak goreng kelapa campuran yaitu $16,28 \mathrm{mEq} \mathrm{O}_{2} / \mathrm{kg}$ dengan nilai tertingginya yaitu $19,17 \mathrm{mEq} \mathrm{O}_{2} / \mathrm{kg}$ dan secara keseluruhan sampel, rerata bilangan peroksida pada minyak goreng yang digunakan oleh pedagang sudah melewati batas maksimal bilangan peroksida pada standar mutu minyak goreng yang ditetapkan SNI nomor 3741 tahun 2013 yaitu $10 \mathrm{mEq} \mathrm{O}_{2} / \mathrm{kg}$. Sebanyak 14 dari 23 sampel minyak goreng memiliki jumlah bilangan peroksida diatas ketetapan SNI. Artinya sebanyak $61 \%$ minyak goreng yang digunakan telah rusak yang ditandai dengan terjadinya perubahan warna pada minyak menjadi kecoklatan hingga kehitaman. ${ }^{1}$ Hasil penelitian ini sejalan dengan penelitian di Kota Samarinda terhadap 4 sampel minyak goreng yang digunakan oleh pedagang gorengan memiliki nilai rerata jumlah bilangan peroksida sesudah beberapa penggorengan melebihi standar SNI yaitu sebesar $32,42 \mathrm{mEq}$ $\mathrm{O}_{2} / \mathrm{kg},{ }^{19}$ Hasil penelitian ini juga sejalan dengan penelitian yang dilakukan Wahyu dkk tahun 2015 
terhadap minyak goreng yang telah dilakukan penggorengan berulang sebanyak empat kali memiliki bilangan peroksida melebihi standar SNI yaitu $18,85 \mathrm{mEq} \mathrm{O}_{2} / \mathrm{kg}$, tetapi hasil penelitian ini tidak sejalan dengan penelitian yang ada di Kota Semarang pada tahun 2018 terhadap minyak goreng yang digunakan oleh penjual gorengan menunjukan hasil 44\% minyak yang digunakan memilki jumlah bilangan peroksida diatas standar SNI dan rerata bilangan peroksida tertinggi yaitu pada minyak goreng bermerek yaitu $11,71 \mathrm{mEq}$ $\mathrm{O}_{2} / \mathrm{kg}^{15,20}$

Peningkatan bilangan peroksida merupakan tanda awal kerusakan minyak yang disebabkan oleh proses oksidasi. Faktor yang dapat menyebabkan bilangan peroksida meningkat antara lain kandungan asam lemak tak jenuh dan proses penggorengan yang berulang. Asam lemak tak jenuh yang terpapar panas secara terus menerus akan mempercepat terjadinya peningkatan bilangan peroksida dikarenakan terjadinya perubahan ikatan pada asam lemak tidak jenuh dan akan membentuk lipid peroksida. ${ }^{5,21}$ Penyimpanan minyak yang tidak sesuai serta tidak dalam wadah tertutup akan mempengaruhi jumlah bilangan peroksida minyak goreng dikarenakan minyak berkontak dengan udara luar atau oksigen dan akan mempercepat terjadinya oksidasi secara spontan. ${ }^{1,10}$ Oleh karena itu, penyimpanan minyak goreng juga harus diperhatikan. Keadaan lingkungan seperti kelembapan udara dan suhu ruangan penyimpanan juga dapat mempengaruhi penyimpanan minyak tersebut. ${ }^{1}$ Wadah terbaik untuk menyimpan minyak goreng adalah berwarna gelap dan tertutup rapat. ${ }^{14}$ Faktor lain yang dapat mempengaruhi tingginya bilangan peroksida yaitu suhu pemanasan, cahaya, lama penggorengan, paparan logam seperti logam dan tembaga serta jenis minyak goreng yang digunakan. Suhu penggorengan yang tinggi yaitu lebih dari $100^{\circ} \mathrm{C}$ akan mempercepat terjadinya proses oksidasi. ${ }^{1,19}$ Nilai rerata bilangan peroksida pada minyak goreng yang digunakan campuran memiliki nilai tertinggi dapat dikarenakan minyak goreng yang telah mengalami proses oksidasi atau yang telah mengalami kerusakan apabila ditambahkan dengan minyak baru akan meningkatkan bilangan peroksida dan dapat menurunkan mutu minyak goreng tersebut. ${ }^{10}$
Pada hasil penelitian juga menunjukkan nilai rerata jumlah bilangan peroksida minyak goreng yang digunakan pedagang gorengan lebih tinggi dari pedagang pecel lele dan pecel ayam yaitu $15,10 \mathrm{mEq} \mathrm{O}_{2} / \mathrm{kg}$ dengan jumlah bilangan peroksida tertinggi yaitu $23,43 \mathrm{mEq} \quad \mathrm{O}_{2} / \mathrm{kg}$ sedangkan rerata bilangan peroksida pada pedagang pecel lele dan ayam yaitu $10,29 \mathrm{mEq}$ $\mathrm{O}_{2} / \mathrm{kg}$ dengan bilangan peroksida tertinggi yaitu $19,17 \mathrm{mEq} \mathrm{O}_{2} / \mathrm{kg}$. Hasil Penelitian ini serupa di Yogyakarta, rerata bilangan peroksida minyak goreng yang digunakan pedagang gorengan mengandung bilangan peroksida diatas $10 \mathrm{mEq}$ $\mathrm{O}_{2} / \mathrm{kg}$ dengan karakteristik minyak berwarna coklat hingga kehitamam, berbau tengik dan terdapat endapan serta berbuih. ${ }^{10} \mathrm{Hal}$ ini selain disebabkan oleh kandungan ikatan asam lemak tak jenuh pada minyak goreng juga dapat disebabkan oleh perbedaan dari jenis bahan makanan yang digoreng. Bahan makanan yang digoreng oleh pedagang gorengan seperti tahu memiliki kadar air yang tinggi. ${ }^{22}$ Bahan yang memiliki kadar air tinggi akan mengakibatkan terjadinya reaksi hidrolisis antara air dan minyak yang akan membentuk asam lemak bebas dan gliserol. ${ }^{1}$ Kecepatan reaksi hidrolisis ini dipengaruhi oleh jumlah air dalam bahan pangan dan suhu saat penggorengan. Semakin tinggi kadar air dalam bahan pangan, semakin cepat reaksi hidrolisis terjadi dan semakin cepat terjadinya pembentukan peroksida. ${ }^{11}$

Mengonsumsi minyak ini akan berdampak pada kesehatan. Pada saluran pencernaan seperti usus halus, dapat terjadi deskuamasi vili-vili dan terbentuknya abses kripta oleh sel polimorfonuklear (PMN) dan dapat membentuk ulserasi yang terlihat seperti gundul pada usus halus. ${ }^{23,24}$

Minyak goreng yang mengandung bilangan peroksida diatas ketetapan SNI atau yang mengandung radikal bebas yang tinggi dapat menyebabkan terjadinya stress oksidatif dikarenakan radikal bebas yang terkandung merupakan salah satu dari sumber pembentukan reactive oxygen species (ROS). ${ }^{25}$ Pembentukan ROS akan menyebabkan kerusakan pada sel-sel hepar dikarenakan sel kuffner, sel stelata, dan sel endotel merupakan sel yang sangat sensitif akan stress oksidatif dan menyebabkan hati menjadi organ target pertama yang terkena dampak dari pembentuk ROS. ${ }^{26}$ Kerusakan yang terjadi pada 
hati dapat berupa jejas reversibel maupun jejas irreversibel.Jejas reversibel salah satunya adalah terjadinya perlemakan hati dikarenakan minyak jelantah mengadung banyak asam lemak yang dapat menyebabkan terakumulasinya trigliserida dalam hepatosit. ${ }^{27}$ Lama kelamaan perlemakan pada hati dapat menyebabkan terbentuknya sirosis hati dan dapat berujung pada karsinoma. ${ }^{27}$ Jejas irreversibel yang terjadi dapat berupa nekrosis sel-sel hepar dikarenakan radikal bebas menghasilkan peroksida yang bersifat lipofilik dan dapat menyerang mitokondria sehingga sel akan mengalami penurunan produksi ATP. ${ }^{27,28}$ Sel akan merespon jejas tersebut dengan membentuk fibrosis yang bermula di sekitar saluran porta dan lama kelamaan akan membentuk jaringan parut. ${ }^{26}$ Kerusakan sel hati pada tikus yang diinduksi minyak jelantah secara mikroskopis terlihat sel inti yang rusak, adanya sel yang mengerut dan sitoplasma terlihat gelap. ${ }^{28}$

Konsumsi minyak ini juga akan menyebabkan tingginya kadar kolesterol dalam darah dikarenakan minyak tersebut juga mengandung asam lemak bebas yang tinggi. Tingginya kadar kolesterol dalam darah sangat berisko akan terjadinya disfungsi endotel.1,29 Asam lemak tersebut akan menumpuk pada pembuluh darah dan menyebabkan peningkatan nitrit oksida yang dapat membuat kontriksi pada pembuluh darah yang kemudian akan menyebabkan terbentuknya plak arterosklerotik sehingga lumen pembuluh darah menjadi mengecil. Lumen yang mengecil dapat menyebabkan aliran darah ke jaringan maupun ke jantung menjadi berkurang dan dapat menyebabkan terjadinya iskemik. ${ }^{29}$ Iskemik juga dapat terjadi pada ginjal. Penelitian menggunakan tikus yang diinduksi minyak jelantah secara makroskopis pada ginjal terlihat adanya edama pada sel epitel tubulus dan adanya penyempitan pada lumen tubulus serta pada delapan kali penggorengan terlihat adanya nekrosis pada tubulus yang ditandai dengan hilangnya inti sel dan nekrosis pada glomerulus yang ditandai dengan hilangnya inti sel disertai warna yang lebih pudar. ${ }^{30}$

\section{Simpulan}

Berdasarkan hasil penelitian ini didapatkan lebih dari setengah sampel yang diteliti memiliki kandungan bilangan peroksida yang tidak sesuai dengan SNI 01-3741-2013. Rerata kandungan bilangan peroksida minyak goreng yang digunakan oleh pedagang gorengan lebih tinggi dari rerata bilangan peroksida minyak goreng yang digunakan oleh pedagang pecel lele dan ayam, sedangkan rerata bilangan peroksida tertinggi dari jenis minyak goreng yang digunakan yaitu pada minyak goreng digunakan secara campuran.

\section{Ucapan Terima Kasih}

Terima kasih penulis sampaikan kepada semua instansi yang telah membatu penyelesaian penelitian ini terutama UPTD Balai Laboratorium Kesehatan Sumatera Barat.

\section{Daftar Pustaka}

1. Ketaren S. Pengantar teknologi minyak dan lemak pangan. Jakarta: UI Press;2008

2. BPS. Rata-rata konsumsi per kapita seminggu beberapa macam bahan makanan penting, 20072018. Badan Pusat Statitiska. https://www.bps.go.id/statictable/2014/09/08/950 /rata-rata-konsumsi-per-kapita-seminggu-beberapamacam-bahan-makanan-penting-2007-2018.html Diakses September 2019

3. Aladedunye FA, Przybylski R. Degradation and nutritional quality changes of oil during frying. Journal of the American Oil Chemists' Society. 2009;86:149-56

4. Aniołowska M, Zahran H, Kita A. The effect of pan frying on thermooxidative stability of fefined rapeseed oil and professional blend. J Food Sci Technol. 2016;53(1):712-20

5. Falade AO, Oboh G. Thermal oxidation induces lipid peroxidation and changes in the physicochemical properties and ß-carotene content of arachis oil. International Journal of Food Science.2015;2015:1-7

6. Okparanta S, Daminabo V, Solomon L. Assessment of rancidity and other physicochemical properties of edible oils (mustard and corn oils) stored at room temperature. Journal of Food and Nutrition Sciences. 2018; 6(3): 70-5

7. Aminah S, Isworo JT. Praktek penggorengan dan mutu minyak goreng sisa pada rumah tangga di RT V RW III kedungmundu tembalang semarang. Laporan Penelitian Internal Unimus.2010;2010:261-7

8. Rauf R. Kimia pangan. Yogyakarta: Andi Cetakan;2015

9. BSN. Minyak goreng. badan standardisasi nasional. http://sispk.bsn.go.id/SNI/DetailSNI/9013 Diakses September 2019

10. Mulasari SA, Utami RR. Kandungan Peroksida pada minyak goreng di pedagang makanan gorengan sepanjang jalan prof. dr. soepomo tahun 2012. Arc. Com. Health. 2012;1(2):120-23

11. Ayu DF, Hamzah FH. Evaluasi sifat fisiko-kimia minyak goreng yang digunakan oleh pedagang makanan jajanan di kecamatan tampan kota pekambaru. E-Journal Universitas Riau. 2010;9(1):414 
12. Megawati M, Muhartono. Konsumsi minyak jelantah dan pengaruhnya terhadap kesehatan. Majority. 2019;8(2):259-64

13. Sutejo IR, Dewi R. Kerusakan sel hati dan peningkatan kolesterol serum mencit akibat pemberian minyak goreng bekas pakai. Jurnal IKESMA. 2012;8(1):9-16

14. Suroso AS. Kualitas minyak goreng habis pakai ditinjau dari bilangan peroksida, bilangan asam dan kadar air. Jurnal Kefarmasian Indonesia. 2013;3(2): 77-88

15. Pangestuti DR, Rohmawati S Kandungan peroksida minyak goreng pada pedagang gorengan di wilayah kecamatan tembalang kota semarang. Jurnal UNAIR. 2018;1:205-11

16. Sari AR, Alioes Y, Semiarty R. Screening kandungan plastic pada minyak goreng yang terdapat pada gorengan di Jati Padang. Jurnal Kesehatan Andalas. 2014;3(3):358-64

17. Lempang IR, Fatimawali, Pelealu NC. Uji kualitas minyak goreng curah dan minyak goreng kemasan di manado. Jurnal Ilmiah Farmasi UNSTRAT. 2016;5(4):155-61

18. Siswanto W, Mulasari SA. Pengaruh frekuensi penggorengan terhadap peningkatan peroksida minyak goreng curah dan fortifikasi vitamin A. Jurnal KESMAS Universitas Ahmad Dahlan. 2015;9(1):1-10

19. Nurhasnawati H, Supriningrum R, Caesariana N. Penetapan kadar asam lemak bebas dan bilangan peroksida pada minyak goreng yang digunakan pedagang gorengan di Jl. A. W Sjahranie Samarinda. 2015;1(1):25-30

20. Siswanto W, Mulasari SA. Pengaruh frekuensi penggorengan terhadap peningkatan peroksida minyak goreng curah dan fortifikasi vitamin A. KESMAS. 2015;9(1):1-10

21. Sartika RAD. Pengaruh suhu dan lama proses menggoreng (deep frying) terhadap pembentukan asam lemak trans. Jurnal Makara Sains. 2009;13(2):23-28

22. Seftiono H. Perubahan sifat fisiko kimia protein selama proses pembuatan tahu sebagai rujukan bagi posdaya. Jurnal Kesejahteraan Sosial Maret. 2017; 3(1): 85-92

23. Ananto AS, Wulan AJ, Oktafany. Pengaruh pemberian minyak jelantah terhadap perbedaan rerata kerusakan gambaran histologi jaringan usus halus tikus jantan (rattus norvegicus) galur sprague dawley. Medical Profession Journal of Universitas Lampung. 2017;7(5):187-93

24. Ilmi IMB, Khomsan A, Marliyati SA. Kualitas minyak goreng dan produk gorengan selama penggorengan dirumah tangga indonesia. Jurnal Aplikasi Teknologi Pangan. 2015;4(2):61-5

25. Widayanti E. Oksidasi biologi, radikal bebas dan antioksidan. Jurnal Unissula. 2012;50(128):1-7

26. Li S, Tan HY, Wang N, Zhang ZJ, Lao L, Wong CW, Feng Y. The Role of oxidate stress and antioxidant in liver disease. International Jurnal of Molecular Science.2015;16(11):26087-124

27. Kumar V, Abbas AK, Aster JC, editors. Buku ajar patologi robbins. Edisi 9. Jakarta: EGC; 2015.p. 7-21

28. Aisyah S, Budiman H, Florenstina D, Aliza D, Salim MN, Balqis U, Armasyah T. Efek pemberian Minyak Jelantah terhadap gambaran histopatologi tikus putih (rattus norvegicus). Jurnal Medika Veterinaria. 2015;9(1):26-9
29. Mitchell RN, editors. Pembuluh darah. In: Kumar V, Abbas AK, Aster JC, editors. Buku ajar patologi robbins. Edisi 9. Jakarta: EGC; 2015. p. 328-38

30. Noventi W, Hanriko R, Imanto M. Pengaruh pemberian minyak jelantah terhadap gambaran histopatologi ginjal tikus putih (Rattus norvegicus) jantan galur sprague dawley. Jurnal Agromedicine. 2019;6(1):159-66 